\title{
任意方向の加力を受ける群杭の杭周水平地盤抵抗の非線形性 NONLINEAR HORIZONTAL SOIL RESISTANCE OF PILE GROUP FOUNDATION SUBJECTED TO ARBITARY DIRECTION LOAD
}

\author{
中野 尊治*, 宮本 裕司**
}

Takaharu NAKANO and Yuji MIYAMOTO

\begin{abstract}
This paper presents the horizontal soil resistance of pile group foundation by the static analyses using 3 -dimensional nonlinear finite element method. Springs both at the pile head and around pile shaft are evaluated and discussed. The major findings obtained from this study are summarized as follows: 1) the horizontal soil resistance is different depending on the location of the pile. 2) soil spring around the pile at the edge of pile group is remarkably influenced by the direction of loading. 3) group-factor of soil spring around the pile is smaller than that of spring at the pile head. 4) when displacement of the pile becomes larger, the difference of soil spring at each pile becomes larger.
\end{abstract}

Keywords : Pile group foundation, Pile group effect, Soil spring, 3D FEM, Nonlinearity, Multi directional motion 群杭基䃈, 群杭効果, 杭周地盤ばね, 三次元有限要素法, 非線形, 多方向入力

1. はじめに

南海トラフ巨大地震や都市直下地震への対策が急務となっている 昨今、杭基礎建物の設計解析モデルの高度化が必要となっている。 極大地震時の杭基礎建物の挙動は、敷地地盤の非線形によるSite Nonlinearity、杭や基礎の近傍地盤の非線形によるLocal Nonlinearity、杭体や上部構造の非線形によるStructure Nonlinearityの影響 を受ける。基礎の耐震性評価においてはこれらの強非線形性を適切 に考慮することが重要となる。特に、近接する杭どうしの間で生じ るLocal Nonlinearity、いわゆる群杭効果の非線形性は、群杭の水平 抵抗に影響を与える。さらに、杭と上部構造に生じる地震力の大き さにも影響し、基礎の部材レベルでの設計を行う上で重要なものと なる。

杭基礎建物の応答評価モデルとして、図1に示す杭を曲げせん断棒 にモデル化した質点系モデルがある。質点系モデルは、上部構造と 杭の応答をそれぞれ独立に算出する「分離型モデル」と、上部構造 と杭を一体としてモデル化する「一体型モデル」に大別される1)。一 体型モデルでは、杭と上部構造の応答を同時に求めることができ、 群杭のモデル化として、群杭を1本の杭に集約する「杭集約モデル」 と、一本一本の杭をモデル化する「杭全体モデル」がある1)。杭集約 モデルでは、杭周地盤ばねに群杭係数を乗じることで群杭効果を考 慮でき、群杭の平均的な応答を算出できる反面、一本一本の杭応力 を直接的に算出できない。これに対して、杭全体モデルでは群杭の 応答を部材レベルで把握することができるが、モデル化にあたって は杭一本一本で異なる杭周地盤抵抗を適切にモデル化する必要があ
る。

群杭の水平抵抗に着目した研究は、実験研究、解析研究ともに数 多く行われている。実験研究として、原位置地盤での静的載荷実験2)-3)、重力場での模型を用いた静的載荷実験4)-7)、発破震動を用いた振 動実験8)、大型振動台や遠心力場での振動台による振動実験9)-10)など

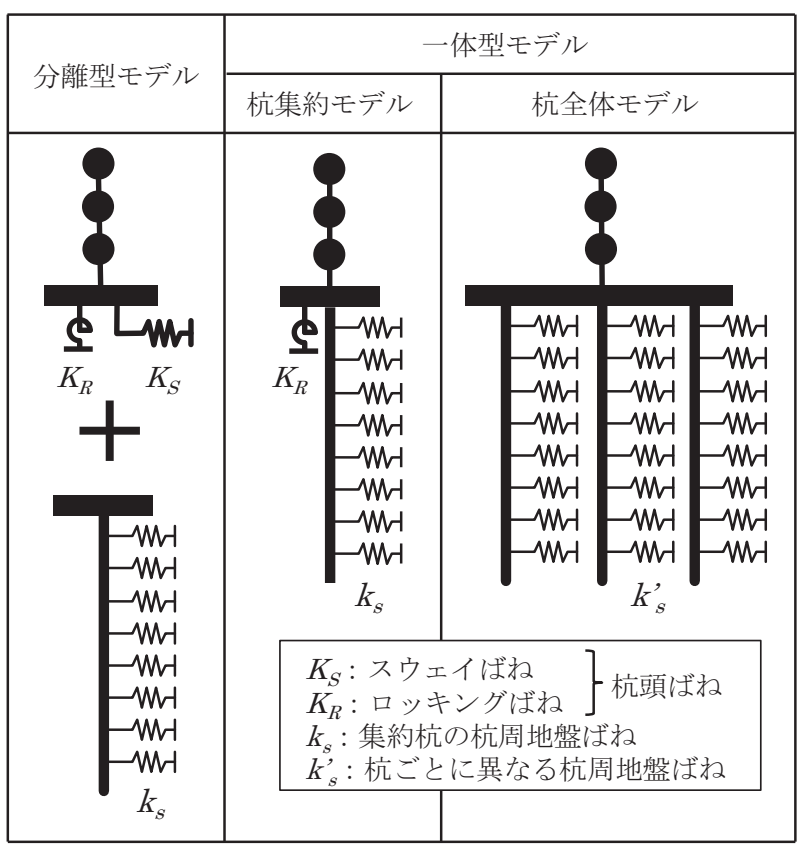

図1 杭基礎の質点系モデルの模式図
* 大阪大学大学院 大学院生 日本学術振興会 特別研究員 (DC1)

** 大阪大学大学院 教授 $\cdot$ 博士 (工学)
Grad. Stud., Osaka University,

JSPS Research Fellow

Prof., Osaka University, Dr.Eng. 
がある。また、解析研究として、理論解に基づく研究11)、薄層法に 基づく研究12)-15)、有限要素法に基づく研究16)-18)などがある。これら の研究の成果として、群杭の杭1本あたりの水平抵抗は単杭のそれを 下回ること、一本一本の杭の水平抵抗は加力方向の前後面や杭位置 によって異なること、群杭効果は杭間隔や杭長、杭剛性、杭変位の 影響を受けて変化することなどが明らかにされている。しかし、こ れらの研究の多くは杭頭ばねの特性に焦点を当てており、杭一本一 本で異なる杭周地盤ばねの非線形特性を求めた研究6),8 2 は限られる。 また、現行の杭周地盤ばねは1方向加力の条件下で構築されている が、地震荷重下では多方向の入力を受けることを鑑みると、任意方 向の加力に対する杭周地盤ばね特性を把握する必要がある。

そこで本研究では、任意方向の加力を受ける群杭の杭周水平地盤 抵抗を、三次元非線形有限要素法を用いた静的解析によって把握す ることを目的とする。本手法の有効性については、既に秀川ら 19)、 柏ら 20)が、杭基礎構造物の遠心模型振動台実験をシミュレーション することにより示している。筆者ら ${ }^{21}$ は、兵庫県南部地震における 群杭の被害要因をシミュレーション解析により明らかにしている。 また、邢ら ${ }^{22)}$ は、重力場での大振幅入力による模型振動台実験をシ ミュレーションしている。

\section{2. 解析方法}

群杭と地盤を三次元有限要素でモデル化し、静的加力によって杭 基礎の杭頭ばねと各杭の杭周地盤ばねを算出する。

\section{1 解析対象の杭基礎と地盤モデル}

本研究では、「単杭」と、杭を正方形に配置した「正方配置の群 杭」、および杭を1列に配置した「列状配置の群杭」を解析対象とす る。解析パラメータは、杭本数 $N_{p}$ 、杭間隔比 $S / B(S$ : 杭中心間隔、
$B$ : 杭径) 、および加力方向とする。杭本数は、正方配置の場合は 4 , $9,16,25,36,49,64,81$ 本とし、列状配置の場合は $2,3,4,5,6,7,8$, 9 本とする。杭間隔比は $2.5,4.0,6.0$ とする。加力方向は、図 $2(b)$ に 示寸群杭の主軸となるX軸とな寸角度 $\theta$ を変数とし、これを $15^{\circ}$ 間隔で 変化させる。杭は、全ての解析を通じて、表1に示すように杭径 $B=600 \mathrm{~mm}$ 、杭長 $L=11 \mathrm{~m}$ 、曲げ岡性 $E I=193 \mathrm{MN} \cdot \mathrm{m}^{2}$ とする。なお、 本解析で設定する $E I$ 、杭径 $600 \mathrm{~mm}$ の PHC杭 (C種) および杭径 $600 \mathrm{~mm}$ 、肉厚 $12 \mathrm{~mm}$ の鋼管杭の初期曲げ剛性に相当する。表層地盤 は厚さ $11 \mathrm{~m}$ で剛基盤上にあるせん断波速度 $V_{S}=110 \mathrm{~m} / \mathrm{s}$ 、内部摩擦角 $\phi=31.9^{\circ}$ の均質地盤とする。

\section{2 解析モデルと解析条件}

図 2 に 25 本杭の解析モデル、表 1 に解析諸元を示す。解析コードは 三次元有限要素法の汎用コードであるLS-DYNA ${ }^{23)}$ を用いる。地盤は 弾塑性体のソリッド要素でモデル化する。地盤の材料非線形モデル については、本解析では、Mohr-Coulomb条件に従う完全弾塑性モ デルを用いる。完全弾塑性モデルを用いる場合、地盤は降伏応力に 達するまでは初期剛性を持つ弾性体として挙動する。一方、地盤は 小さいひずみ領域から徐々に塑性化するため、完全弾塑性モデルで 初期せん断岡性を $\rho \cdot V_{S} 2 （ \rho:$ 密度、VS : せん断波速度）とする と、地盤が降伏するまでの剛性を大きめに評価すると考えられる 20)。これを避けるために、本解析では、初期せん断剛性を $0.5 \rho \cdot V_{S}{ }^{2}$ として用いる21)。なお、このような初期せん断剛性の設定方法の妥 当性については 3.1 節で検討する。

地盤の境界条件は、底面を剛基盤、側面を固定条件とする。側面 境界については、モデル化する地盤全体の領域を十分に大きく取る ことにより、杭の水平抵抗に及ぼす境界条件の影響を小さくしてい る。地盤一杭間には滑り、剥離、再接触を考慮できるペナルティ法

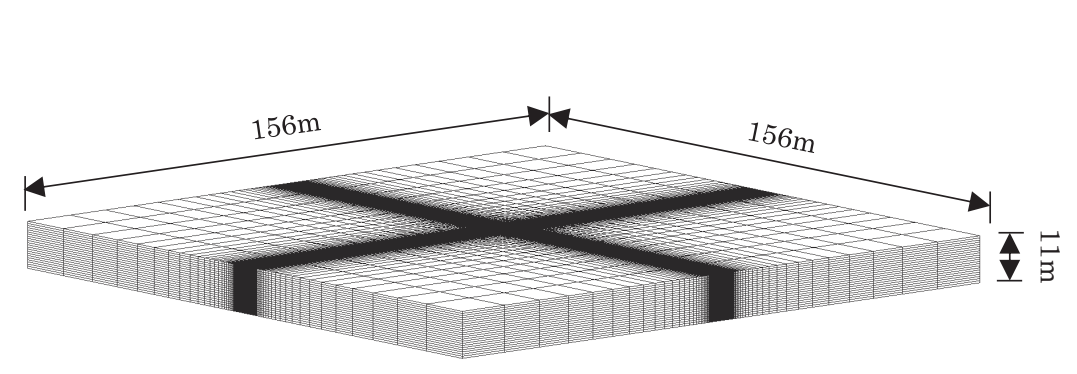

(a) モデル全体図

図2 三次元有限要素解析モデル（25本杭、S/B=2.5）

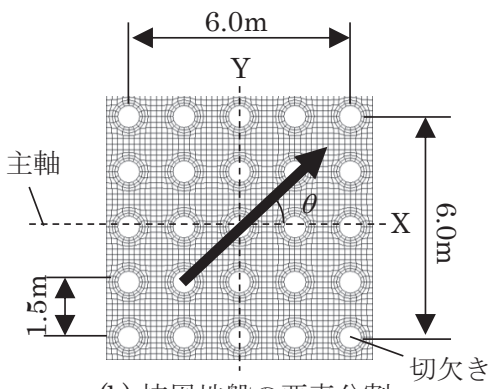

(b) 杭周地盤の要素分割
表1 解析諸元

\begin{tabular}{l|l|r}
\hline \multirow{4}{*}{ 杭 } & 杭径 $B$ & $600 \mathrm{~mm}$ \\
& 杭長 $L$ & $11 \mathrm{~m}$ \\
& 曲げ剛性 $E I$ & $193 \mathrm{MN} \cdot \mathrm{m}^{2}$ \\
\hline \multirow{5}{*}{ 地盤 } & 層厚 & $11 \mathrm{~m}$ \\
& 質量密度 $\rho$ & $1.8 \mathrm{t} / \mathrm{m}^{3}$ \\
& S波速度 $V S$ & $110 \mathrm{~m} / \mathrm{s}$ \\
& ポアソン比 $v$ & 0.33 \\
& 内部摩擦角 $\phi$ & $31.9^{\circ}$ \\
& 粘着力 $c$ & $0.001 \mathrm{~N} / \mathrm{mm}^{2}$ \\
\hline
\end{tabular}

(1)杭頭に強制変位

(2)全ての杭の杭頭変位は等しい

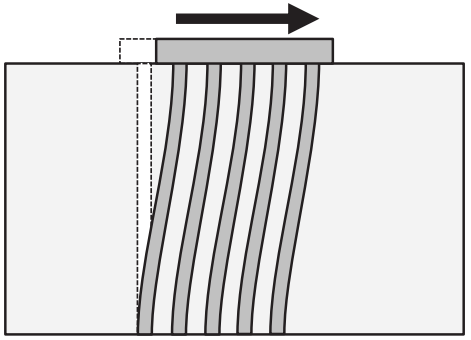

(a) 杭頭ばね
(1)杭長方向に一様な強制変位 (2)全ての杭の変位は等しい

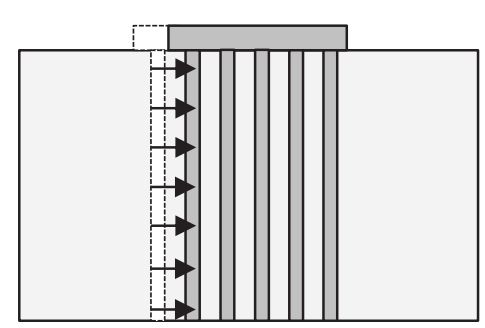

(b) 杭周地盤ばね

図3杭頭ばねと杭周地盤ばねの算出時に仮定する杭の変形モード 
に基づく接触条件を与え、接触面の静止および動摩擦係数は $\tan \phi$ ( $\phi$ : 内部摩擦角) とする。載荷ステップは単調載荷、もしくは正負 交番漸増載荷（変位振幅 $\pm 1 \mathrm{~mm}, \pm 2 \mathrm{~mm}, \pm 5 \mathrm{~mm}, \pm 10 \mathrm{~mm}, \pm 20 \mathrm{~mm}$, $+30 \mathrm{~mm})$ とし、特に断らない限り単調載荷による結果を示寸。杭は 弾性体とし、モデル化については次節で述べる。

\section{3 杭頭ばねと杭周地盤ばねの算出方法}

群杭の水平抵抗として、図1に示した杭頭ばねと杭周地盤ばねを、 それぞれ図3に示すように杭の変形モードを仮定することによって算 出する。

\section{(1) 杭頭ばねを算出する場合}

杭を弾性体のシェル要素としてモデル化する。杭の曲げ剛性は、 PHC杭の初期曲剬性相当とする。杭の境界条件は、杭頭を剛基礎 で剛接合とし、杭先端を固定条件とする。剛基礎の回転は拘束す る。この条件下で杭頭に対して強制水平変位を与えて算出した杭頭 せん断力一杭頭変位関係を、杭頭ばねの力ー変形関係とする。

\section{(2) 杭周地盤ばねを算出する場合}

杭位置に相当する部分の地盤を円形に切欠いた「中空切欠き地 盤」としてモデル化し、全ての杭に杭長方向に一様でかつ等しい強 制水平変位を与える13)。この時に得られた各深さ位置における杭周 地盤反力一杭変位関係を、杭周地盤ばねの力一变形関係とする。

\section{3. 杭頭ばねの群杭効果}

本章では、既往の研究で多く取り扱われている杭頭位置における 群杭の水平抵抗の基本的性状を把握する。検討では、群杭を1本に集 約した「杭頭集約ばね」の杭頭せん断力と、個々の杭について求め た杭頭せん断力を考える。

\section{1 杭頭ばねのカー変形関係}

図4に、杭頭ばねのカー変形関係として、(a)に単杭の杭頭せん断 力一杭頭変位関係、 (b)に $S / B=2.5$ の正方配置の 25 本杭における 1 本あ たりの平均杭頭せん断力一杭頭変位関係、(c)に同じ 25 本杭における 杭頭集約ばねの群杭係数一杭頭変位関係を示す。ここで、杭頭変位 $u$ における杭頭集約ばねの群杭係数 $\alpha_{H}$ は、各杭の杭頭せん断力を用い て(1)式の通りに定義する。

$$
\alpha_{H}(u)=\frac{\sum_{i} Q_{i}(u)}{N_{p} \cdot Q_{S}(u)}
$$

ここに、 $Q_{1}(u)$ : 杭頭変位 $u$ をええた時の $i$ 杭の杭頭せん断力、 $N_{p}:$ 杭 本数、 $Q_{S}(u)$ : 杭頭変位 $u$ をえた時の単杭の杭頭せん断力

なお、図中には完全弾塑性モデルの初期せん断剛性の設定方法の 妥当性を確認するために、初期せん断剛性 $\rho \cdot V_{S}{ }^{2}$ の完全弹塑性モデ ル (Model1)、初期せん断剛性 $0.5 \rho \cdot V_{S} 2$ の完全弾塑性モデル (Model2)、および、地盤のせん断応力ーひずみ関係を小さいひずみ 領域から連続的に考慮できる多折れ線モデル(Model3)20)による結果 を示している。Model3のせん断応力ーせん断ひずみ関係はHDモデ ルに合わせて、初期せん断剛性は $\rho \cdot V_{S}$ 2、せん断強度はMohrCoulomb条件より算出している。図5に各モデルのせん断応力一せん 断ひずみ関係の一例を示す。

25本杭の平均杭頭せん断力は、同じ杭頭変位を与えた単杭の杭頭 せん断力を下回る。群杭係数は、杭頭変位 $1 \mathrm{~mm}$ 近傍で極小となった 後、杭頭変位の増大とともに増大し、杭頭変位 $20 \mathrm{~mm}$ で概祆横這い となる。次に、地盤の材料非線形モデルの設定が杭頭ばねに及ぼす 影響を見ると、単杭において、Model2を用いて求めた杭頭せん断力 は、Model3を用いた場合に良く対応する。一方、Model1を用いて求

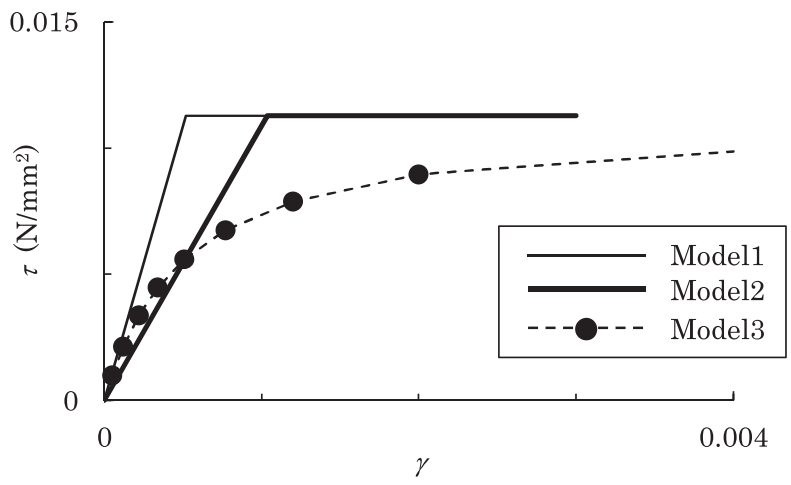

図5 材料非線形モデルの せん断応カーせん断ひずみ関係（GL-1.5m）

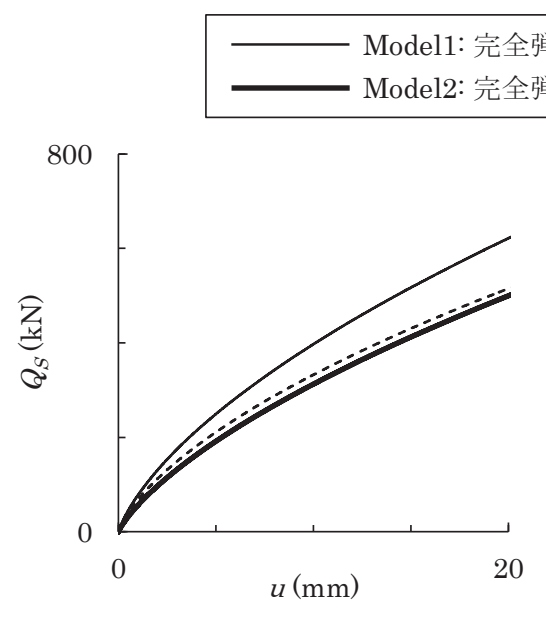

(a) 単杭の 杭頭せん断力一変位関係

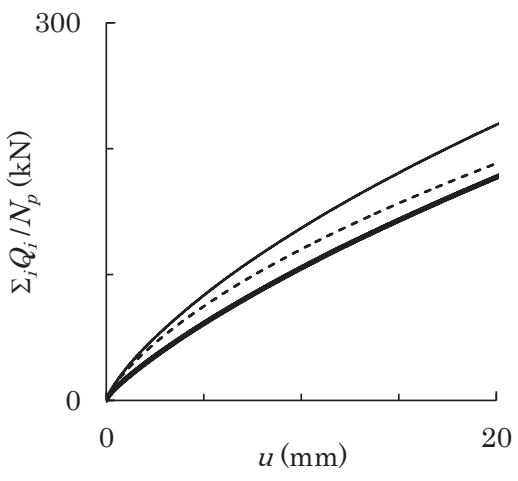

(b) 25 本杭 $(S / B=2.5)$ の 平均杭頭せん断力一変位関係

図4杭頭ばねのカー変形関係
Model3: 多折れ線モデル

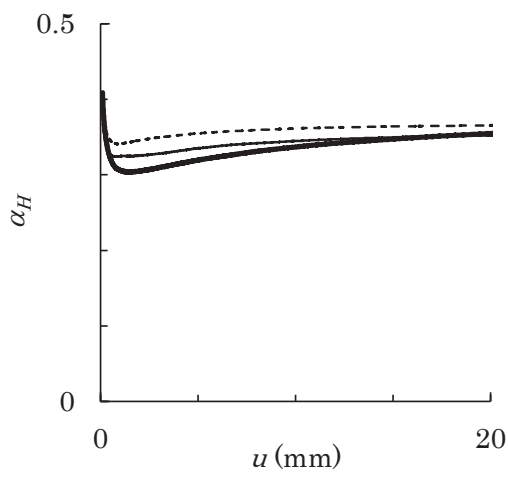

(c) 25 本杭 $(S / B=2.5)$ の 群杭係数一変位関係 

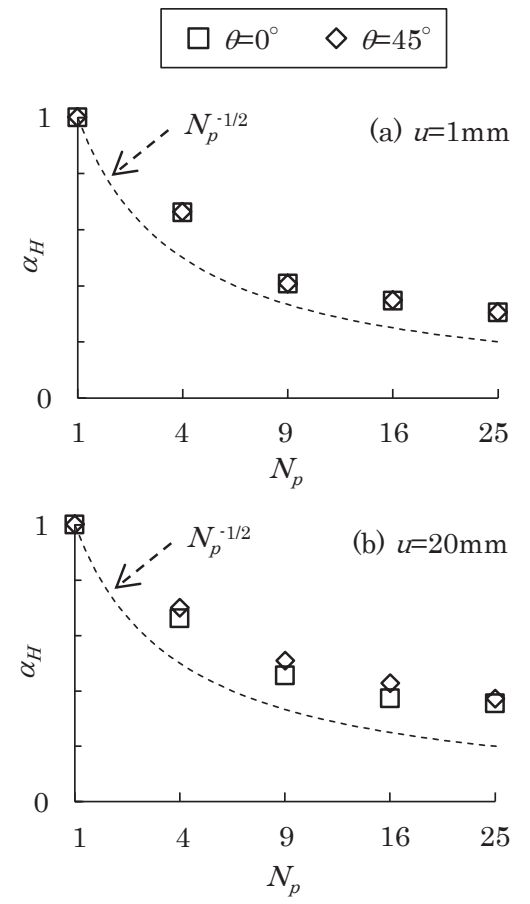

図6杭頭集約ばねの群杭係数一杭本数関係 $(S / B=2.5)$

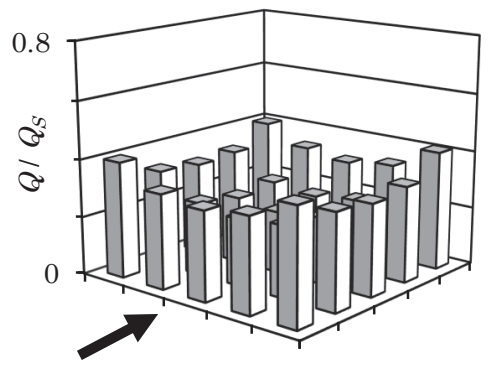

$\theta=0^{\circ}, u=1 \mathrm{~mm}$

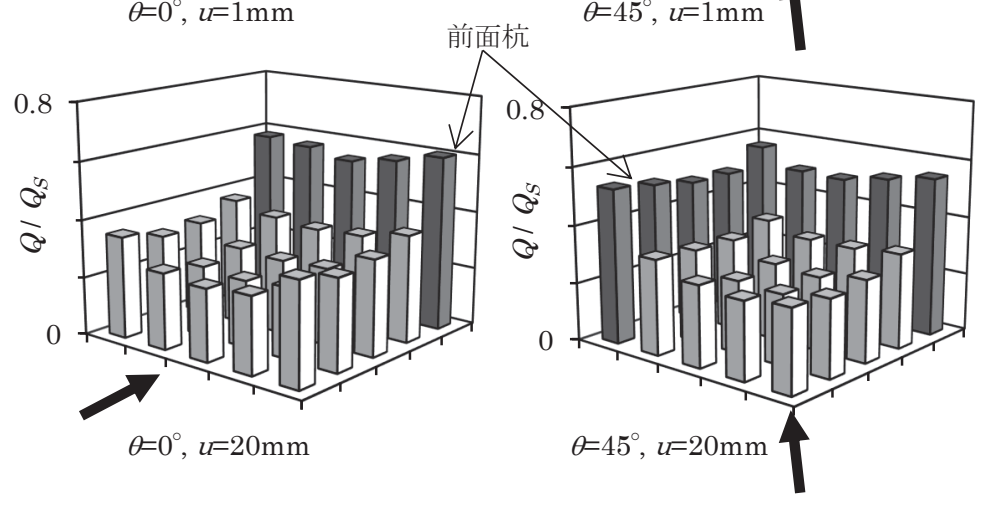

図7 各杭の無次元杭頭せん断力の平面分布 (25本杭、 $S / B=2.5$ )
めた杭頭せん断力は過大評価となる。25本杭について見ると、 Model2を用いて求めた杭頭せん断力の方がModel3に良く対応する。 群杭係数についても、Model2はModel3に近い結果となっている。以 上のことから、地盤の材料非線形モデルとして、以下の検討では

Model2を用いる。

\section{2 群杭係数一杭本数関係}

図6に、S $S / B=2.5$ の正方配置の群杭について、杭頭集約ばねの群杭 係数一杭本数関係を、 $\theta=0^{\circ}, 45^{\circ}$ で比較して示す。戝には代表変位と して、地盤がほぼ弾性範囲に留まる杭頭変位 $1 \mathrm{~mm}$ と、極限地盤反力 に達しないものの地盤の塑性化が進行する杭頭変位 $20 \mathrm{~mm}$ の結果を 示す。図より、杭頭変位と日によらず、杭本数が多くなるにつれて群 杭係数は小さくなる。既往の研究では群杭係数は概数杭本数の-1/2乗 程度になるとされるが14)、本解析で得られた群杭係数はこれをやや 上回る。群杭係数に対する $\theta$ の影響を見ると、杭頭変位 $1 \mathrm{~mm}$ の場合 は、 $\theta$ にらず群杭係数は概ね同程度の值となる。これに対して、杭 頭変位が $20 \mathrm{~mm}$ に達すると、 $\theta=45^{\circ}$ の場合の群杭係数が $\theta=0^{\circ}$ の場合に 比べやや大きくなる。

\section{3 杭ごとに算出した杭頭せん断力の平面分布}

個々の杭について求めた杭頭ばねの特性について考察する。図 7 に、S/B=2.5の正方配置の 25 本杭について、杭頭変位 $1 \mathrm{~mm}, 20 \mathrm{~mm} に$ おける杭頭せん断力の平面分布を示す。ここで、杭頭せん断力は単 杭の杭頭せん断力で除して無次元化している。杭頭变位 $1 \mathrm{~mm}$ の場合 の杭頭せん断力は、 $\theta$ によらず隅杭で大きく中央杭で小さい、すり鉢 状の分布となる。杭頭変位が $20 \mathrm{~mm}$ に達すると、 $\theta=0^{\circ}$ の場合に 5 本の 杭が前面杭となって、他の杭に比べ2倍程度の杭頭せん断力を負担し ており、文献16)の傾向と整合する。一方、 $\theta=45^{\circ}$ の場合には9本の杭 が前面杭となり、他の杭に比べ2倍程度の杭頭せん断力を負担する。

\section{4 杭ごとの杭頭せん断カー加力方向関係}

図 8 に、 $S / B=2.5$ の正方配置の 25 本杭について、杭頭変位 $1 \mathrm{~mm}$, $20 \mathrm{~mm}$ における代表杭の杭頭せん断力と加力方向との関係を示寸。

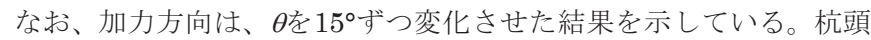
せん断力は単杭の杭頭せん断力で除して無次元化している。また、 図中の「平均」は25本の杭頭せん断力の平均值を表しており、杭頭 集約ばねに相当する。まず杭頭変位 $1 \mathrm{~mm}$ について見ると、B杭（外 周中杭）、E杭（中央杭）の杭頭せん断力は、加力方向によらず概补 一定の值となる。また、B杭は全杭を平均した值と同程度となる。こ れに対して、C杭（隅杭）では日によって杭頭せん断力が変化する。 すなわち、側方杭となる $\theta=135^{\circ}, 315^{\circ}$ で $\mathrm{C}$ 杭の杭頭せん断力が最大と なり、前面杭もしくは背面杭となる $\theta=45^{\circ}, 225^{\circ}$ でC杭の杭頭せん断 力が最小となる。

次に、杭頭変位 $20 \mathrm{~mm}$ について見ると、 $\mathrm{B}$ 杭と $\mathrm{C}$ 杭の杭頭せん断力 は $\theta$ によって大きく変化する。B杭の杭頭せん断力は、前面杭となる $\theta=90^{\circ}$ で最大となり、背面杭となる $\theta=225^{\circ} \sim 315^{\circ}$ で最小となる。C杭 の杭頭せん断力は、前面杭となる $\theta=0^{\circ}, 90^{\circ}$ で最大となり、背面杭と なる $\theta=225^{\circ}$ で最小となる。また、 $\mathrm{B}$ 杭、C杭の最大值は全杭の杭頭せ 几断力の平均值を大きく上回る。このように、杭変位が大きい場合 には、外周杭の杭頭せん断力は加力方向によって著しく変化する。

\section{4. 杭周地盤ばねの群杭効果}

杭頭せん断力が杭位置や加力方向によって変化するのは、杭周で の地盤抵抗が影響していることによると考えられる。そこで本章で は、GL-1.5m位置での杭周地盤ばねに焦点を当てて考察を行う。こ こで、GL-1.5mは、前章で $S / B=2.5$ の 25 本杭に杭頭変位 $20 \mathrm{~mm}$ 与え た際に隅杭位置にあるC杭の杭周地盤反力が最大となった深さであ 

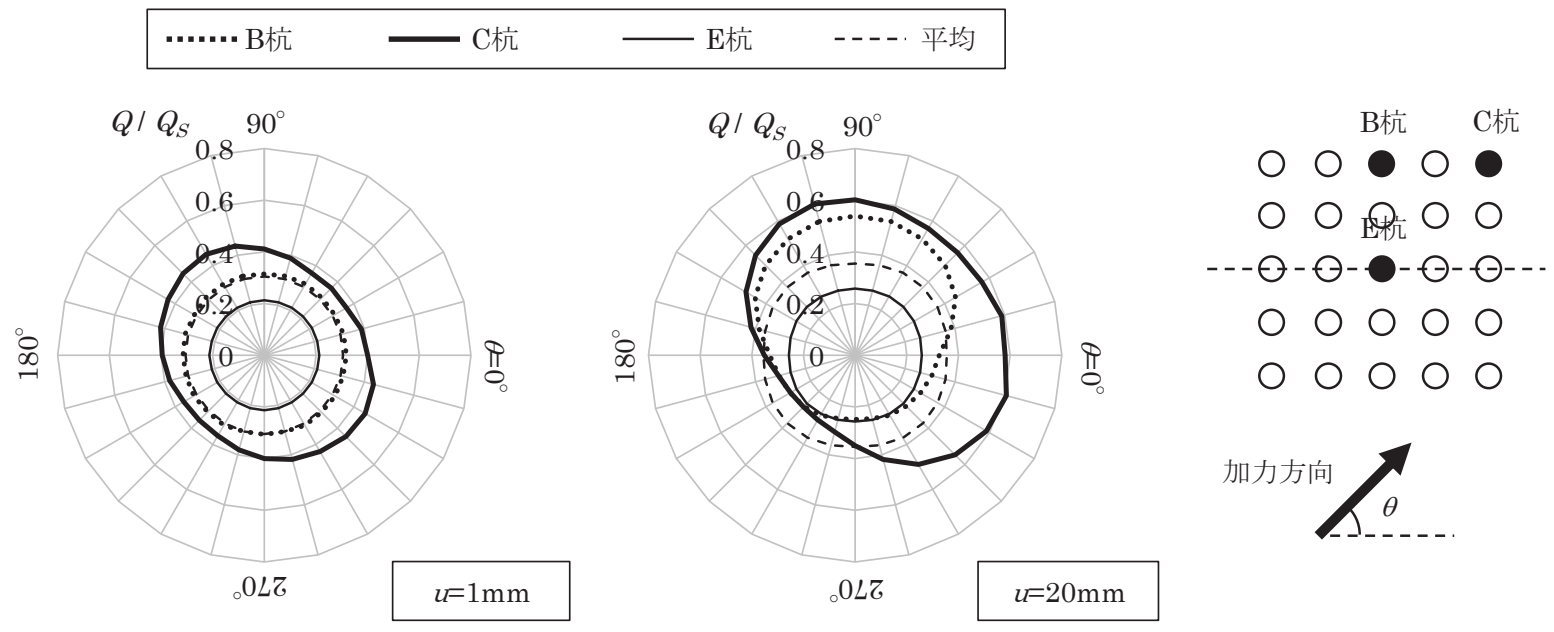

図8 杭位置の違いによる杭頭せん断カー加力方向関係 $(25$ 本杭、 $S / B=2.5)$

る。杭周地盤ばねについても、群杭を1本に集約した「杭周集約地盤 ばね」と、個々の杭について求めた杭周地盤ばねについて分析す る。

\section{1 群杭係数一杭本数関係}

杭変位 $u$ におる深さ $Z$ 位置での杭周地盤ばねの群杭係数 $\beta_{H}$ を、各 杭の杭周地盤反力を用いて(2)式の通りに定義する。

$$
\beta_{H}(u, z)=\frac{\Sigma_{i} p_{i}(u, z)}{N_{p} \cdot p_{S}(u, z)}
$$

ここに、 $p_{i}(u, z):$ 杭変位 $u$ をちえた時の $i$ 杭の深さ $Z$ 位置における杭周 地盤反力、 $N_{p}$ : 杭本数、 $p s(u, z)$ : 杭変位 $u$ をえた時の深さZ位置に おける単杭の杭周地盤反力

図9に、S/B=2.5の列状配置の群杭について、GL-1.5m位置の杭周 集約地盤ばねの群杭係数と杭本数との関係を、 $\theta=0^{\circ}, 45^{\circ}, 90^{\circ}$ で比較 して示す。杭変位 $1 \mathrm{~mm}$ の場合は、 $\theta=0^{\circ}$ の直列方向に比心゙、 $\theta=90^{\circ}$ の 並列方向で群杭係数はやや大きくなり、加力方向による違いが見ら れる。杭変位 $20 \mathrm{~mm}$ では、群杭係数は $\theta=0^{\circ}$ の場合に比べ $\theta=45^{\circ}$ の場合 に1.2〜1.5倍、 $\theta=90^{\circ}$ の場合に $1.4 \sim 2.0$ 倍程度となり、 $\theta$ による群杭係 数の変化がさらに大きくなる。

図10に、S/B=2.5の正方配置の群杭について、GL-1.5m位置の杭周 集約地盤ばねの群杭係数と杭本数との関係を、 $\theta=0^{\circ}, 45^{\circ}$ で比較して 示す。図中には、弾性支承梁の理論解に基づく杭頭ばねと杭周地盤 ばねの関係式「 $\left.\left.\beta_{H}=\alpha_{H}^{4 / 3}\right\rfloor 1\right)$ に、杭頭ばねの群杭係数之杭本数 $N_{p}$ の関 係式「 $\left.\left.\alpha_{H}=N_{p}^{-1 / 2}\right\rfloor 14\right)$ を代入して得た「 $\left.\beta_{H}=N_{p}^{-2 / 3}\right\rfloor$ を併せて示してい る。図より、群杭係数は概衩杭本数の-2/3乗となり、杭頭ばねの群杭 係数に比べると小さい值となる。群杭係数に対する $\theta$ の影響を見る と、杭変位 $1 \mathrm{~mm}$ の場合は、 $\theta$ によらず群杭係数は概ね同程度の值と

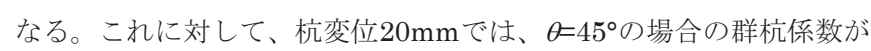
$\theta=0^{\circ}$ に比べ $7 \sim 11 \%$ 程度大きくなるものの、列状配置の群杭に比べる と日による群杭係数の変化は小さい。

\section{2 杭ごとに算出した地盤反力の平面分布}

個々の杭で算出した杭周地盤ばねについて考察する。

図11に、S/B=2.5の列状配置の 5 本杭について、杭変位 $1 \mathrm{~mm}$,
$20 \mathrm{~mm}$ におけるGL-1.5m位置での杭周地盤反力の平面分布を示す。 ここで、杭周地盤反力は、単杭の杭周地盤反力で除して無次元化し ている。杭変位 $1 \mathrm{~mm}$ の場合について見ると、 $\theta$ によらず、前方杭お よび最後方杭の杭周地盤反力が大きく中杭の杭周地盤反力が小さい ブシネスク型の分布となる。杭変位 $20 \mathrm{~mm}$ の場合について見ると、 $\theta=0^{\circ}, 45^{\circ}$ の場合には、1本の杭が前方杭となって、それぞれ他の杭の 2.5倍、1.6倍程度の杭周地盤反力を負担している。これに対して、 $\theta=90^{\circ}$ の場合には、全杭で杭周地盤反力が概ね均等に発生している。

図 12 に、 $S / B=2.5$ の正方配置の 25 本杭について、杭変位 $1 \mathrm{~mm}$, $20 \mathrm{~mm}$ における GL-1.5m位置での杭周地盤反力の平面分布を示す。 杭変位 $1 \mathrm{~mm}$ の場合の杭周地盤反力は、 $\theta$ によらず、隅杭で大きく中 央杭で小さい、すり鉢状の分布となる。各隅杭について見ると、 $\theta=0^{\circ}$ の場合には 4 本の隅杭全てで概称同程度の杭周地盤反力が発生す るのに対し、 $\theta=45^{\circ}$ の場合には前面中杭となるC杭の杭周地盤反力が 側方杭となるA杭とI杭の杭周地盤反力に比べ $2 / 3$ 程度となる。杭变位 $20 \mathrm{~mm}$ では、 $\theta=0^{\circ}$ の場合に 5 本、 $\theta=45^{\circ}$ の場合に 9 本の杭が前面杭と なって、それぞれ他の杭の 3.6 倍、3.7倍程度の杭周地盤反力を負担寸 る。杭位置の違いによる杭周地盤反力の差は、図7に示した杭頭せん 断力の差に比べ顕著となる。図13に、同じ25本杭について、杭変位 20mmでのGL-1.5m位置の杭周地盤で発生したvon Mises応力のコン ター図を示す。杭間地盤では応力がほとんど発生していないのに対 し、図12で前面杭となった杭の前方地盤に大きな応力が発生してい る。このような地盤応力の違いが、一本一本の杭で杭周地盤反力が 異なった原因であると考えられる。

\section{3 杭ごとの杭周地盤反カー加力方向関係}

図 14 に、 $S / B=2.5$ の正方配置の 25 本杭について、杭変位 $1 \mathrm{~mm}$, $20 \mathrm{~mm}$ における GL-1.5m位置での代表杭の杭周地盤反力と加力方向

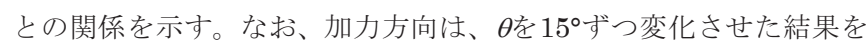
示している。杭周地盤反力は単杭の杭周地盤反力で除して無次元化 している。また、図中の「平均」は25本の杭周地盤反力の平均值を

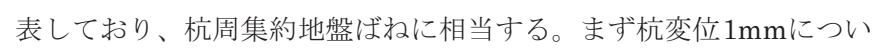
て見ると、B杭、 $\mathrm{E}$ 杭の杭周地盤反力は、加力方向によらず概衩一定 の值となるのに対して、C杭では加力方向によって杭周地盤反力が変 

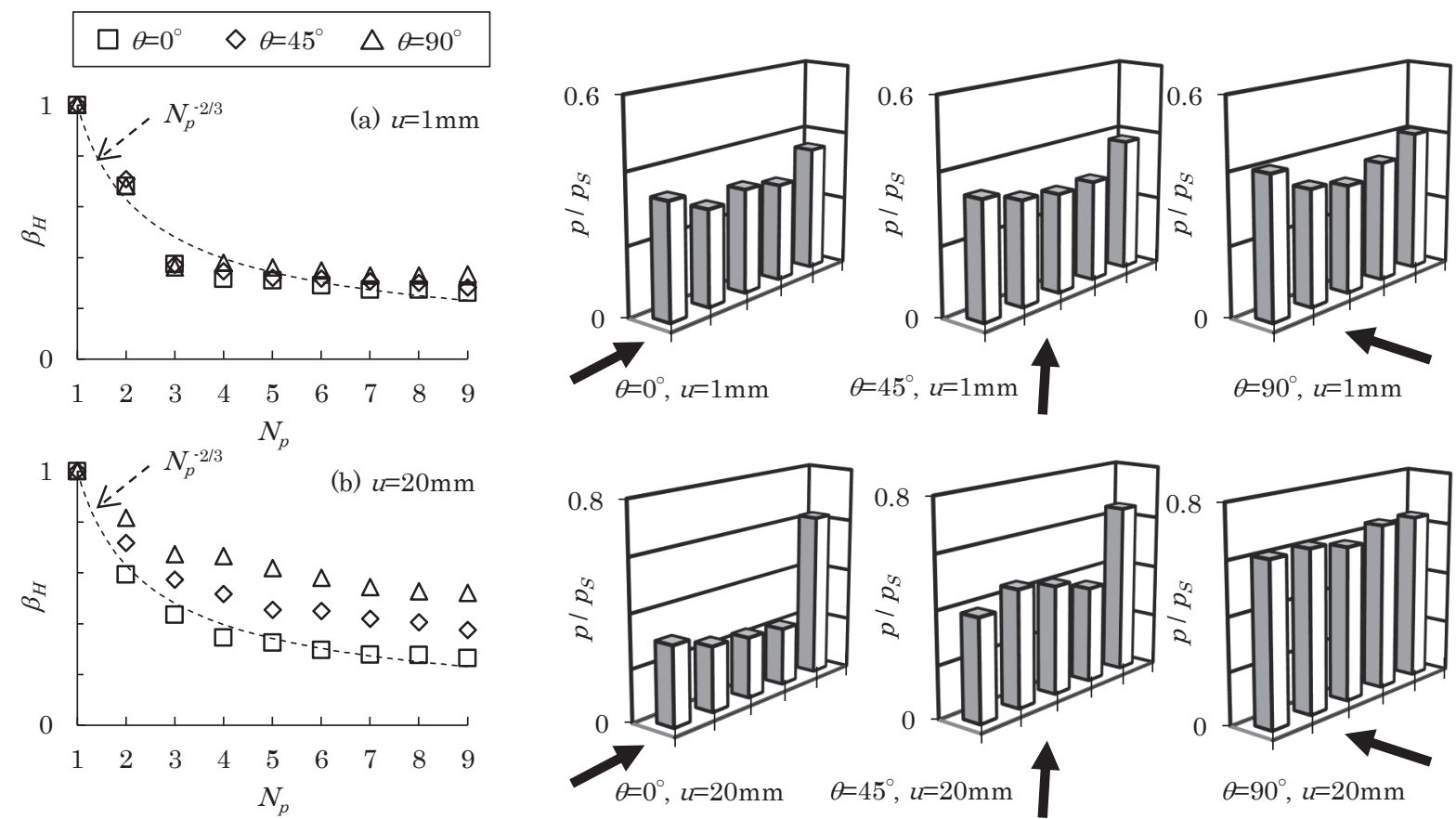

図9杭周集約地盤ばねの群杭係数一杭本数関係 （列状配置、 $S / B=2.5 、 G L-1.5 m$ )

図11 各杭の無次元地盤反力の平面分布 (5本杭、 $S / B=2.5 、 G L-1.5 \mathrm{~m}$ )
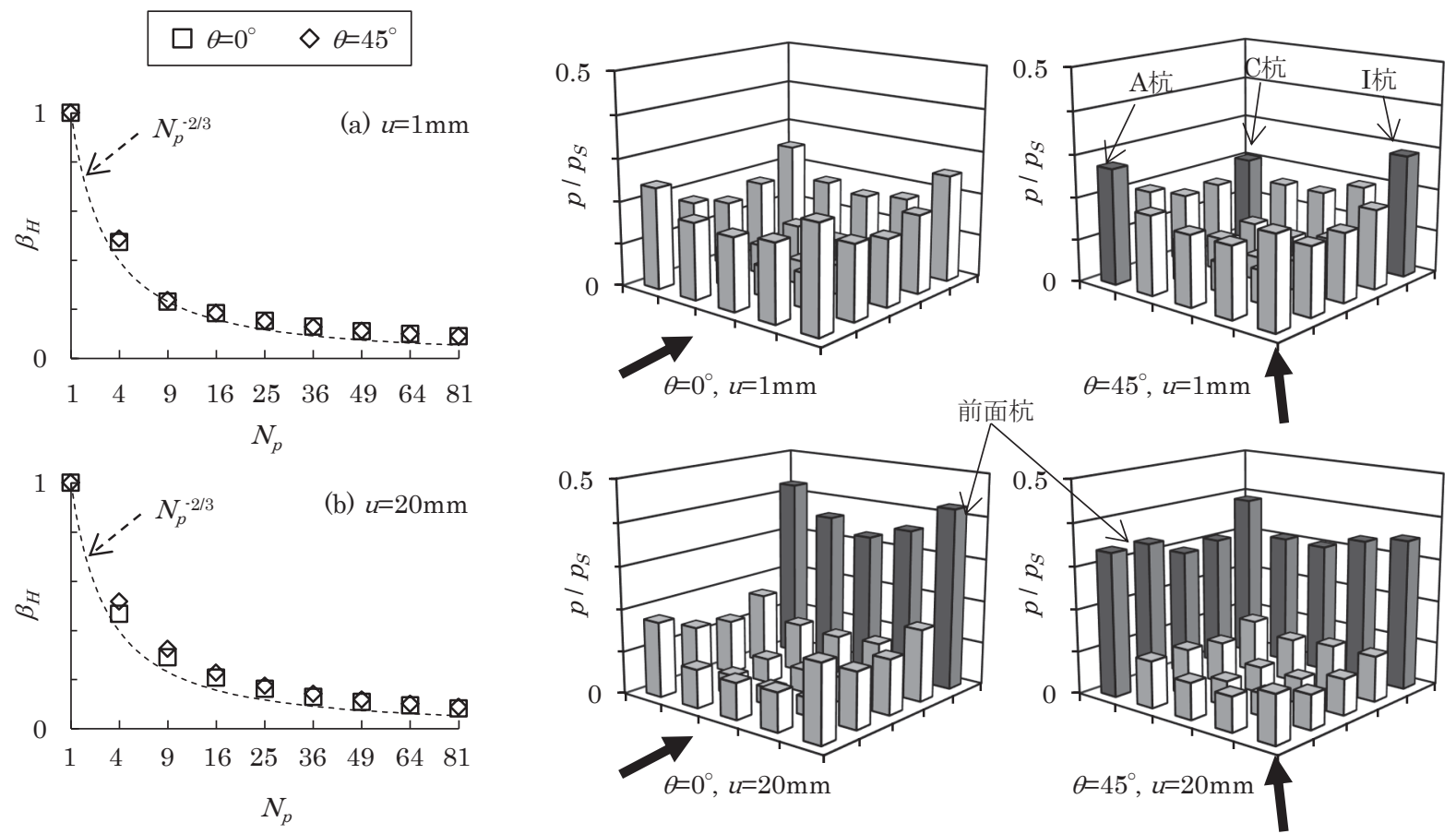

図10 杭周集約地盤ばねの群杭係数一杭本数関係 （正方配置、 $S / B=2.5 、 G L-1.5 \mathrm{~m}$ )

図12 各杭の無次元地盤反力の平面分布 (25本杭、S/B=2.5、GL-1.5m)

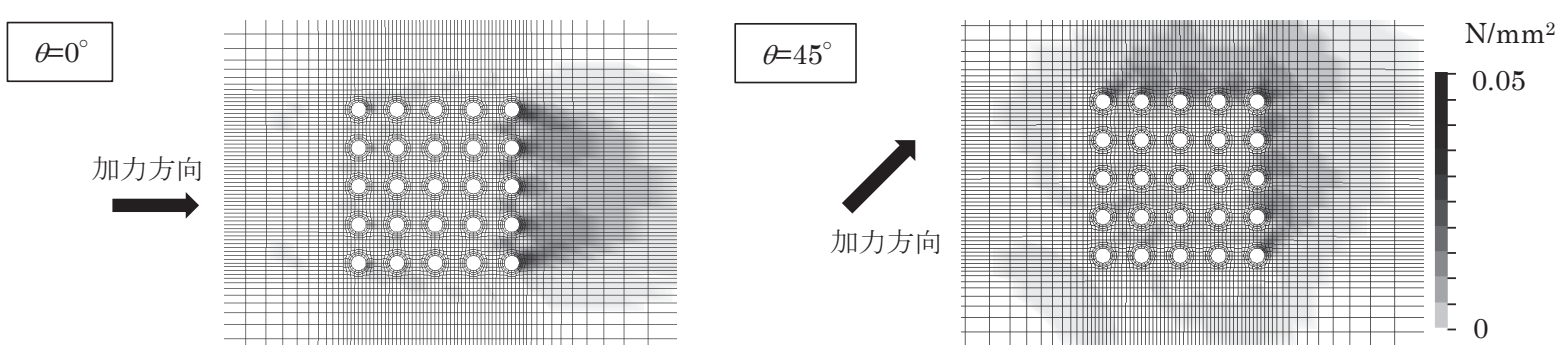

図13杭周地盤のvon Mises応力分布

(25本杭、S/B=2.5、u=20mm、GL-1.5m) 


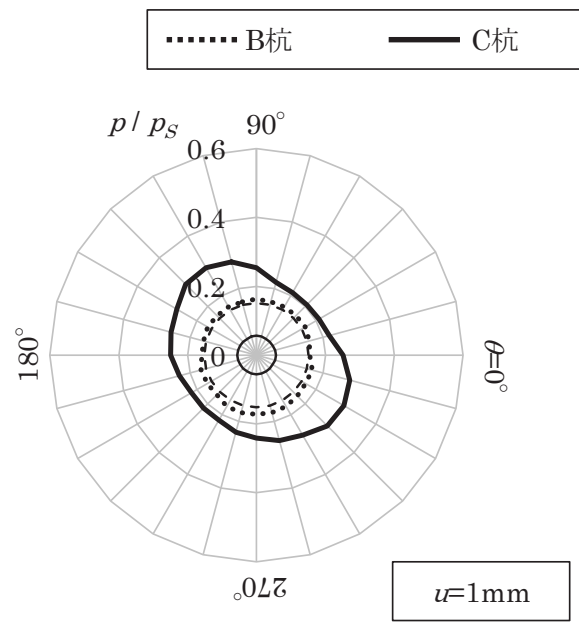

— E杭 - - . 平均

図14 杭位置の違いによる杭周地盤反カー加力方向関係（25本杭、S/B=2.5、GL-1.5m）

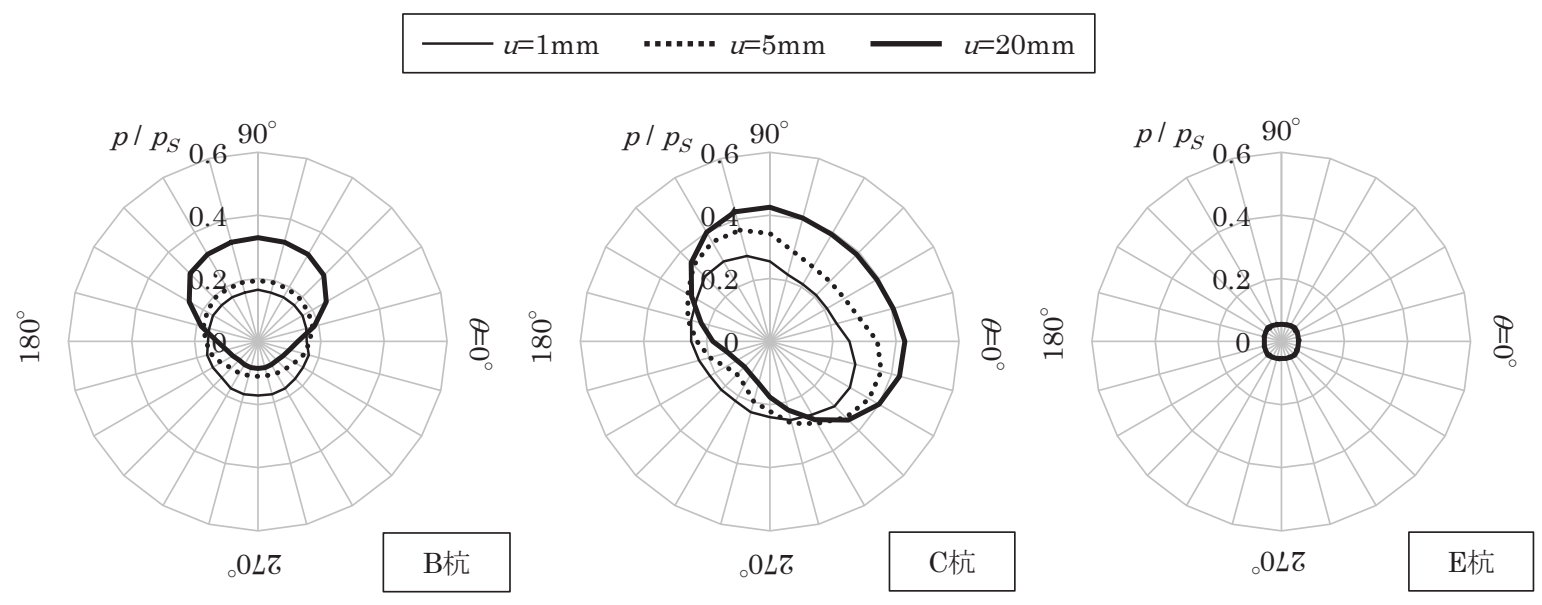

図15 杭変位の違いによる杭周地盤反カー加カ方向関係（25本杭、 $S / B=2.5 、 G L-1.5 m)$

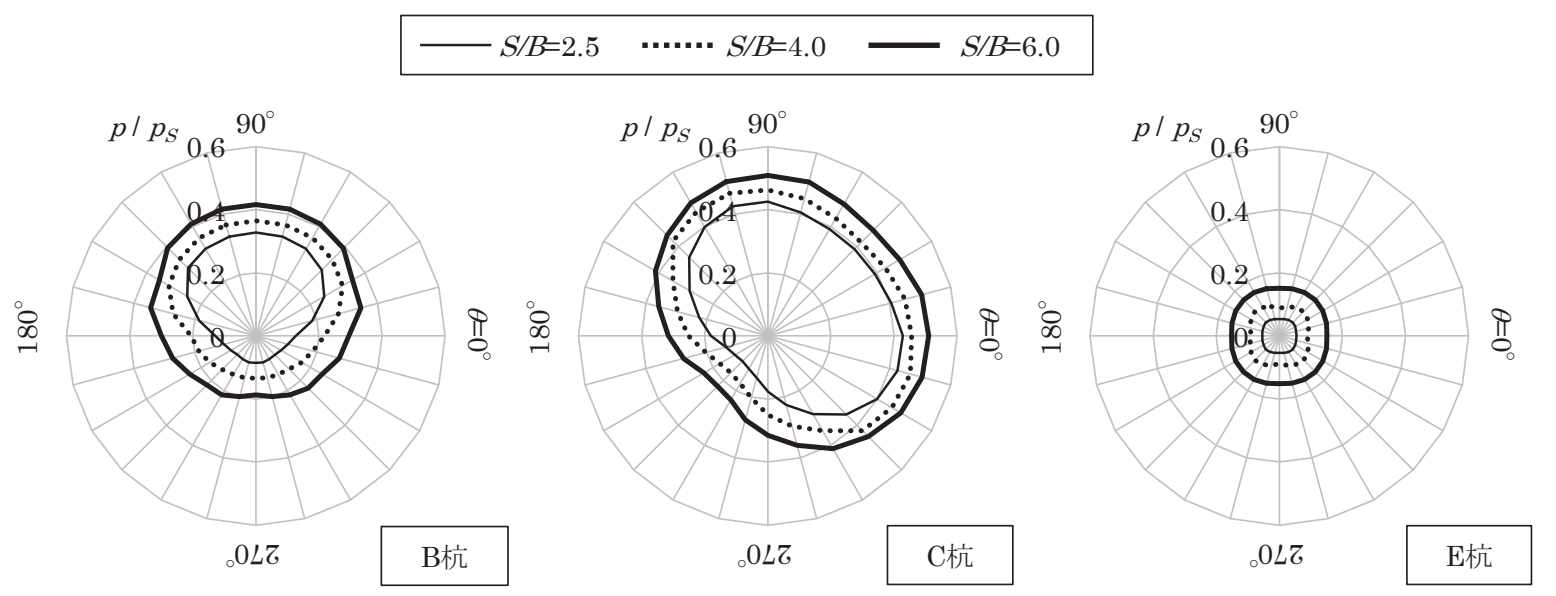

図16 杭間隔の違いによる杭周地盤反カー加カ方向関係（25本杭、 $u=20 \mathrm{~mm} 、 \mathrm{GL}-1.5 \mathrm{~m}$ )

化する。C杭の杭周地盤反力は、側方杭となる $\theta=135^{\circ}, 315^{\circ}$ で最大と なり、前面もしくは背面杭となる $\theta=45^{\circ}, 225^{\circ}$ で最小となる。次に、 杭変位 $20 \mathrm{~mm}$ について見ると、B杭と $\mathrm{C}$ 杭の杭周地盤反力は加力方向 によって大きく变化する。C杭の杭周地盤反力は、前面杭となる $\theta=0^{\circ}, 90^{\circ}$ で最大となり、背面杭となる $\theta=225^{\circ}$ で最小となる。また、 $\mathrm{C}$ 杭は $\theta=0^{\circ} \sim 135^{\circ}, 315^{\circ} \sim 360^{\circ}$ という広い範囲の $\theta$ において応力の集 中寸る前面杭となる。一方、B杭の杭周地盤反力は、前面杭となる $\theta=90^{\circ}$ で最大となり、背面杭となる $\theta=225^{\circ} \sim 315^{\circ}$ で最小となる。杭 変位と $\theta$ によらず、杭周地盤反力は $\mathrm{C}$ 杭、 $\mathrm{B}$ 杭、 $\mathrm{E}$ 杭の順に小さくな る。このように、杭周地盤反力においても杭頭せん断力と同様に、 杭位置と加力方向による違いが明瞭に認められる。

図 15 に、 $S / B=2.5$ の正方配置の 25 本杭の各杭について、杭変位を 変化させた場合の杭周地盤反力一加力方向関係を示す。 $\mathrm{B}$ 杭と $\mathrm{C}$ 杭で は、前面杭となる場合には杭変位の増大とともに単杭に対する杭周 


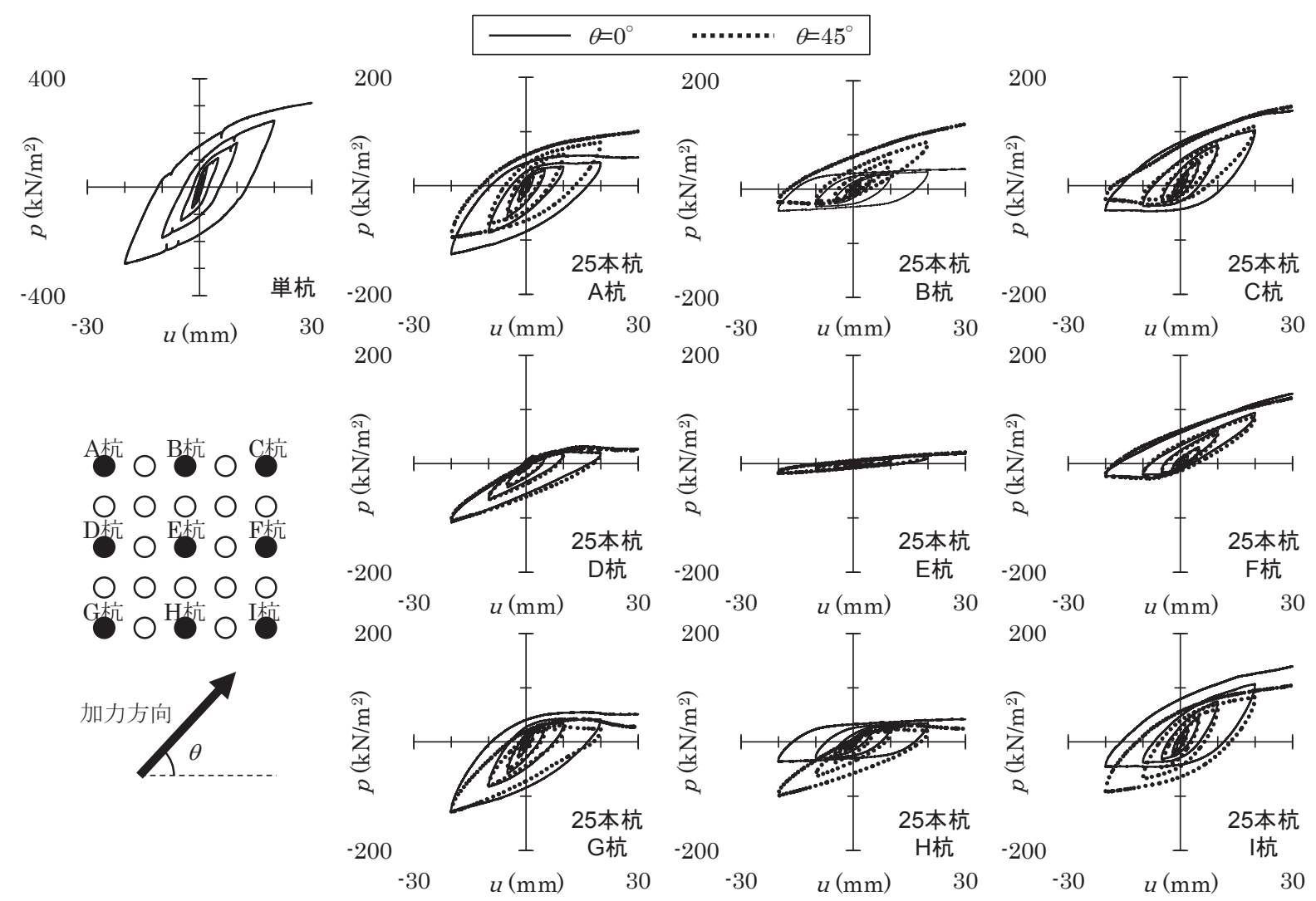

図17 25本杭の加力方向が異なる杭周地盤抵抗の履歴曲線（ $S / B=2.5 、 G L-1.5 m ）$

地盤反力の比が大きくなり、逆に背面杭となる場合には小さくな る。したがって、杭変位が大きいほど、外周杭となる $\mathrm{B}$ 杭と C杭では 加力方向による杭周地盤反力の差が顕著になる。

図16に、S/Bが異なる25本杭の各杭について、変位 $20 \mathrm{~mm}$ をえた 時の杭周地盤反力一加力方向関係を示す。 $\theta$ によらず、杭間隔が広い ほど地盤反力が大きくなる。S/Bを2.5から6.0に変化させると、杭周 地盤反力は、B杭、C杭の背面杭となる向きおよびE杭では2倍以上に なるのに対し、B杭、C杭の前面杭となる向きでは高々 1.3 倍程度で あり、加力方向によって $S / B$ に対する地盤反力の影響が異なる。ま た、基礎指針24)で群杭効果が小さくなるとされる $S / B=6.0$ において も、杭周地盤反力は単杭に比べ $\mathrm{B}$ 杭、 $\mathrm{C}$ 杭の前面側で $0.4 \sim 0.5$ 倍、背 面側で 0.2 倍、E杭で 0.1 倍程度となっている。すなわち、依然として 各杭の杭周地盤反力が単杭を下回っており、杭位置と加力方向によ る杭周地盤反力の違いが認められる。なお、文献6)では $S / B=10$ の群 杭で杭頭位置での群杭効率（本論文の $\alpha_{H}$ に相当）が約 0.7 となること が実験的に示されている。また、本解析で群杭の杭周地盤反力が小 さくなる理由として、杭頭加力時と異なり杭の全長にわたって一様 な変位を与えているため、杭間地盤の抵抗が小さめに評価されてい ることによる。

\section{4 杭周地盤ばねの履歴特性}

図17に、正方配置の 25 本杭に対して $\theta=0^{\circ}, 45^{\circ}$ で正負交番漸増載荷 を行った場合の、GL-1.5m位置における各杭の杭周地盤反力一变位 関係を示す。比較として単杭の結果も併記する。25本杭では単杭の 履歴性状に比べ、各杭で杭周地盤の抵抗性状が異なる。加力方向の 前方に他の杭がある場合は杭周地盤の抵抗が小さくなるため、杭位
置によって杭周地盤抵抗が描く履歴ループの形状が異なる。すなわ ち、 $\theta=0^{\circ}$ 場合、加力方向の前後に他の杭がある $\mathrm{B}, \mathrm{E}, \mathrm{H}$ 杭では、正 負対称かつ履歴面積の小さなループを描くのに対し、片側にのみ他 の杭のある A, C, D, F, G, I杭では、前面杭となる向きで履歴面積の 大きい非対称なループを描いている。 $\theta=45^{\circ}$ の場合、 A, E, I杭で正負 対称なループ、 B, C, D, F, G, H杭で正負非対称なループを描く。

次に、隅杭である $\mathrm{A}, \mathrm{C}$ 杭に着目して $\theta=0^{\circ}, 45^{\circ}$ のループを比較する と、杭変位 $20 \mathrm{~mm}$ において、C杭では、 $\theta$ によらず、前面杭となる場 合では同程度の杭周地盤反力となる。これに対して、背面杭となる 場合では $\theta=45^{\circ}$ の杭周地盤反力が $\theta=0^{\circ}$ の半分程度となる。一方、 $\mathrm{A}$ 杭 の杭周地盤反力は、 $\theta=0^{\circ}$ の前面杭となる場合、 $\theta=45^{\circ} 、 \theta=0^{\circ}$ の背面杭 となる場合、の順に小さくなる。

5. まとめ

本研究では、三次元非線形有限要素法を用いて群杭の水平地盤抵 抗を解析的に把握した。以下に、得られた知見をまとめて示寸。

（1）正方配置の群杭の杭頭ばねと杭周地盤ばねについて、群杭係 数一杭本数関係を算出した。杭頭ばねの群杭係数は杭本数の-1/2 乗をやや上回っていたのに対し、杭周地盤ばねの群杭係数は概 ね杭本数の-2/3乗であり、杭周地盤ばねの方が群杭効果が大き い。

（2）杭変位が大きくなると、加力方向によって杭頭ばね、杭周地盤 ばねの群杭係数が変化する。特に列状配置の群杭では正方配置 に比べ加力方向による群杭係数の変化はより顕著になる。

（3）杭変位が大きくなると、杭周地盤反力は前面杭でより大きく、 
背面杭でより小さくなる。特に隅杭では、応力集中する加力方 向の範囲が広くなる。

（4）杭間隔が広くなると、杭位置と加力方向による群杭効果は小さ くなり、地盤反力は大きくなる。杭間隔が杭周地盤反力に及ぼ す影響は、中杭と背面杭で大きく、前面杭で小さい。また、杭 間隔比6.0においても、依然として各杭の杭周地盤抵抗は単杭を 下回っており、かつ杭位置と加力方向による杭周地盤抵抗の違 いが認められる。

（5） 25 本の正方配置の杭の杭周地盤ばねの履歴特性は、載荷方向の 前後に杭がある中杭では、正負対称で履歴面積の小さいループ を描く。一方、端杭で前方杭となる方向では履歴面積の大きい 非対称なループを描く。加力方向の異なる隅杭での杭周地盤ば ねの特性として、前面杭となる場合、側方杭となる場合、背面 杭となる場合、の順に大変位時の杭周地盤反力が小さくなる。

以上より、群杭の杭周水平地盤抵抗が杭位置、加力方向、および 杭変位によって大きく変化することを示した。大地震時の杭応力評 価を精度良く行う上で、本研究で得られた杭周地盤ばねの諸特性を 適切に解析モデルに考慮することが重要であると考えられる。な お、著者らは本研究結果を実証するための模型振動台実験を実施し ており、今後、その成果を報告する予定である。

\section{謝辞}

本研究は、日本学術振興会特別研究員奨励費 $26 \cdot 725$ (研究課題 名：「極大地震時における杭の損傷過程の解明と杭基礎建物の耐震 性能評価法の開発」、代表者：中野尊治）の補助の下で実施したも のである。ここに記して謝意を表します。

\section{参考文献}

1） 日本建築学会：建物と地盤の動的相互作用を考慮した応答解析と耐震設 計, 2006.2 .

2）斎藤亮, 飯古道則, 五瀬伸吾, 易鋒 : 杭基礎の水平方向大変形時の挙動に 関する研究，構造工学論文集，Vol.39A，pp.1395-1408，1993.3.

3）幸左賢二, 鈴木直人, 木村亮, 木村嘉富, 森田悠紀雄 : 終局挙動に着目し た実物大杭基礎の水平載荷試験，土木学会論文集 第596号，pp.249$260,1998,6$.

4) 玉置修, 三橋晃司, 今井常雄 : 水平抵抗における群杭効果の研究, 土木学 会論文報告集 第192号，pp.79-89，1971.8.

5）小野勇, 山田清臣, 菊田征勇, 松浦聖, 岡田勝也 : 粘性土地盤における群 杭の水平大変形挙動の実験的検討, 土木学会論文集 第645号, pp.223$233,2000.3$.

6）鈴木康嗣, 安達直人：模型水平載荷試験による群杭の地盤反力～変位関 係, 日本建築学会構造系論文集, 第570号, pp.115-122, 2003.8.

7）柏尚稳, 倉田高志，林康裕，田村修次，吹田啓一郎：大振幅水平載荷実験 による群杭効果の振幅依存性，日本建築学会構造系論文集，第614号， pp.53-60, 2007.4.

8）土方勝一郎，杉山達也，伊東賢伸，藤原一成，酒向裕司，宮本裕司：群杭 基礎の非線形挙動に関する振動実験及び実験研究 -25 本杭試験体の実験 結果とシミュレーション解析, 日本建築学会構造系論文集 第 615 号, pp.109-117, 2007.5.

9）鈴木比吕子, 時松考次 : 大型振動台を用いた杭一地盤一構造物系の動的相 互作用実験，日本地震工学会誌，No.10，pp.26-30，2009.7.

10）周友吴, 時松孝次, 眞野英之: 転倒モーメントが群杭内水平力分布に与え る影響に関する実験及び解析的検討，日本建築学会構造系論文集 第709 号, pp.427-434, 2015.3.

11）冨永晃司，山肩邦男：地盤の塑性状態を考慮した群ぐいの水平抵抗理論 一その 1 塑性地盤反力について一, 日本建築学会論文報告集 第317号, pp.32-40, 1982.7 .
12）喜多村英司，宮本裕司，三浦賢治，増田潔：埋込みを有寸る群杭基礎の地 震応答性状に関する研究, 日本建築学会構造系論文集 第492号, pp.53$60,1997.2$

13）宮本裕司，酒向裕司，喜多村英司，三浦賢治：非線形，液状化地盤におけ る杭基礎の地震応答性状に関寸る研究, 日本建築学会構造系論文集 第 471号，pp.44-50，1995.5

14）土方勝一郎, 今村晃, 柳下文雄, 富井隆, 小山桂介 : 群杭係数の評価方法 に関する研究, 日本建築学会構造系論文集 第476号, pp.57-66, 1995.10 .

15）護雅史, 森川和彦: 加振方向を考慮した群杭効率の推定式の提案, 第3回 日本地震工学会研究発表会, pp.416-417, 2004.

16）土方勝一郎他：3D-FEMに基づく群杭地盤ばねの非線形特性，その $1 \sim 6$, 日本建築学会学術講演梗概集，B-1，pp.435-440，2006.7；日本建築学会 学術講演梗概集, B-1, pp.623-628, 2007.7.

17）成田修英, 金子治, 根本恒, 金井重夫, 新井寿昭 : 杭位置の影響を考慮し た群杭の非線形水平地盤ば叔簡易評価手法, 日本建築学会構造系論文集 第676号, pp.877-882，2012.6.

18）土方勝一郎，井原和弘，柳下文雄，間瀬辰也：非線形群杭係数の変動特性 に関寸る研究, 日本建築学会構造系論文集 第709号, pp.411-418, 2015.3.

19）秀川貴彦，岸本美季，柏尚稔，宮本裕司，田村修次：杭一地盤系の非線形 性を考慮した杭基礎建物の地震応答性状, 日本建築学会構造系論文集 第 661号，pp.491-498，2011.3.

20）柏尚稔, 宮本裕司：杭の塑性化に着目した遠心載荷実験のシミュレーショ ン解析に基づいた大地震時の杭頭損傷評価, 日本建築学会構造系論文集 第694号, pp.2133-2142，2013.12.

21）中野尊治, 柏尚稔, 宮本裕司: 兵庫県南部地震の震度 7 地域で損傷した杭 基䃈建物のシミュレーション解析, 日本建築学会構造系論文集, No.692, pp.1965-1704, 2013.10.

22）邢爽，柏尚稳，中野尊治，宮本裕司：極大地震時の杭および改良体の外周 地盤の強非線形化が杭基礎建物の応答に及ぼす影響, 日本建築学会構造系 論文集，No.710，pp.583-591，2015.4.

23）日本総研ソリューションズ：LS-DYNA Version 971 User's Manual Volume 1,2, 2007.6.

24）日本建築学会：建築基礎構造設計指針，2001.10. 


\title{
NONLINEAR HORIZONTAL SOIL RESISTANCE OF PILE GROUP FOUNDATION SUBJECTED TO ARBITARY DIRECTION LOAD
}

\author{
Takaharu NAKANO* and Yuji MIYAMOTO** \\ * Grad. Stud., Osaka University \\ JSPS Research Fellow \\ ** Prof., Osaka University, Dr.Eng.
}

Many studies have been done about the horizontal soil resistance of pile group foundation through experimental and analytical approach. These studies gave us the following results:

1) The horizontal resistance per one pile in pile group becomes smaller compared with that of single pile.

2) The horizontal resistance at each pile is different depending on the locations in pile group.

3) Pile group effect varies depending on the pile spacing, soil-to-pile stiffness ratio, and displacement of the piles.

These studies are mainly focusing on the spring at the pile head. There are few studies which evaluated the soil spring around pile shaft at each pile. Pile foundation is also subjected to the load of various direction during earthquake, it is necessary to define the soil spring to arbitrary direction. Therefore this study presents the horizontal soil resistance of pile group to arbitrary direction based on the static analyses using nonlinear 3-dimensional finite element method.

In this study, the soil-pile system is modeled by 3-dimensional finite elements. Both springs at the pile head and around pile shaft are calculated and discussed. When calculating the spring at the pile head, the piles are modeled by the elastic shell elements and forced displacement is given to the pile head. When calculating the soil spring around pile shaft, the piles are modeled as the excavated ground and uniform forced displacement is given to the whole of the piles.

The major findings obtained from this study are summarized as follows:

1) The relationship between group-factor and the number of piles $\left(N_{p}\right)$ is evaluated as for both springs at the pile head and around pile shaft. The group-factor of the spring at the pile head is slightly larger than $N_{p}^{-1 / 2}$, and that of the soil spring around pile shaft is approximately equal to $N_{p^{-2 / 3}}$.

2) When displacement of the piles is large, the group-factor varies depending on the direction of loading. This trend is conspicuous by $1 \times 5$ piles in linear arrangement more than $5 \times 5$ piles in box arrangement.

3) When displacement of the piles becomes larger, the difference in the horizontal soil resistance of the front piles and the back piles becomes larger.

4) When the pile spacing is large, the horizontal soil resistance of the piles becomes large. Influence in the pile spacing is stronger in the horizontal resistance of the middle and back pile than that of the front pile.

5) The hysteresis curve of the soil spring at the middle piles is symmetric with small hysteresis loop area. The hysteresis curve of the soil spring at the edge piles is asymmetric. Ultimate subgrade reaction of the corner pile varies by direction of loading. It becomes the largest in the case of the front pile, followed in order by the side pile, the back pile. 